\title{
KREATIVITAS MERANCANG LOGO BATIK MELAYU "ASIMILASI INDOLAYSIA" MELALUI PENGGABUNGAN BUDAYA DUA NEGARA
}

\author{
Pujiyanto $^{1}$, Robby Hidajat ${ }^{2}$, Nurul Aini ${ }^{3}$, Swastika Dhesti Anggriani ${ }^{4}$, Nazlina Shaari ${ }^{5}$ \\ 1,2,3,4 Universitas Negeri Malang, ${ }^{5}$ Universiti Putera Malaysia \\ pujiyanto.fs@um.ac.id ${ }^{1}$, robbyhidajat.fs@um.ac.id ${ }^{2}$, nurulaini.ft@um.ac.id ${ }^{3}$, \\ Swastikadhestianggriani.fs@um.ac.id ${ }^{4}$,nazlinashaari@upm.edu.my ${ }^{5}$
}

\begin{abstract}
Abstrak
Klaim-mengklaim batik pernah terjadi antara Indonesia dengan Malaysia. Hal ini menyebabkan hubungan kedua negara kurang harmonis. Berdasarkan pengalaman ini, penulis Universitas Negeri Malang dan Universitas Putera Malaysia melakukan penelitian dan penciptaan motif batik serumpun Malayu yang dapat dimiliki bersama dan dapat dikembangkan bersama. Motif batik yang diciptakan tersebut hingga saat ini belum memiliki logo merek sebagai identitas diri. Maka dari itu perlu diciptakan logo merek yang didekatkan dengan budaya di kedua negara serumpun Melayu. Nilai-nilai budaya Melayu dan kelslaman sangat mendominasi pada logo tersebut secara visual maupun verbal. Sebelum menciptakan logo diperlukan penelitian lapangan dengan menggunakan metode deskripstif kualitatif yang datanya diperoleh melalui observasi, wawancara, dokumen, dan kepustakaan. Agar data valid lebih bermakna maka dilakukan proses triangulasi kemudian dianalisis yang hasilnya sebagai dasar untuk mendesain logo dengan menggunakan teori kreativitas dari Bryan Lawson bahwa dalam proses mendesain dapat dilakukan melalui first insight, preparation, incubation, illumination, dan verification. Melalui tahapan proses kreatif inilah tercipta logo merek batik "Asimilasi Indolaysia" sebagai hasil penggabungan artefak budaya Indonesia dengan Malaysia. Terciptanya logo ini diharapkan dapat peningkatan keharmonisan dua negara yang saling menghormati, memiliki, serta mengembangkan hasil budaya serumpun Melayu.
\end{abstract}

Kata kunci: artefak Melayu, asimilasi budaya, deformasi bentuk, logo merek

\begin{abstract}
The claim of batik has occurred between Indonesia and Malaysia. It causes the relations between the two countries to be less harmonious. Based on this experience, authors of Universitas Negeri Malang and Universitas Putera Malaysia conducted research and created a Malay cognate batik pattern that can be shared and developed together. The batik pattern created so far does not have a brand logo as their identity. Therefore, it is necessary to create a brand logo that is closer to the culture in the two countries of Malay cognate. Malay cultural values and Islamic values dominate the logo visually and verbally. Before creating a logo, field research needed by using a qualitative descriptive method, in which data obtained through observation, interviews, documents, and literature. To gain more meaningful valid data a triangulation process is analyzed. The results of which used as the basis for designing a logo using Bryan Lawson's theory of creativity that the process of designing can be done through first insight, preparation, incubation, illumination, and verification. Through the stages of this creative process, the batik brand logo "Asimilasi Indolaysia" was created as a result of the merging of Indonesian cultural artifacts with Malaysia. The creation of this logo expected to increase harmony between the two countries that respect each other, possess, and develop the Malay cognate's cultural output.
\end{abstract}

Keywords: brand logo, cultural assimilation, deformation of forms, malay artifacts 


\section{PENDAHULUAN}

Suatu produk perlu adanya legalitas formal berupa logo merek. Adanya logo dapat memperkuat jati diri dan sebagai media informasi perusahaan maupun produk agar mudah dikenal masyarakat. Bagaimana bila suatu produk tidak memiliki nama atau logo merek, tentu masyarakat akan kebingungan dalam memilih satu produk, karena banyak produk sejenis beredar di pasaran. Bagaimana bila seseorang pergi ke luar kota yang dititipi temannya untuk membelikan oleh-oleh produk tertentu tanpa menyebutkan satu nama merek. Setelah sampai di tempat yang dituju merasa kebingungan karena produk yang pesan banyak jenisnya, yang mana akan dibeli karena temannya tidak menebutkan merek produk yang diinginkan. Untuk menghindari kesalahpahaman tersebut perlu ada nama merek beserta logonya yang melekat pada suatu produk, seperti halnya produk batik bernafaskan Melayu yang dikembangkan Universitas Negeri Malang yang saat ini hanya memiliki nama merek sekunder, namun belum memiliki merek primer. Beberapa desain batik dan nama motif sudah diciptakan hingga mendapatkan Hak Atas Kekayaan Intelektual (HaKI), hanya logo sebagai merek priner belum diciptakan. Berdasarkan diskusi antara pihak Universitas Negeri Malang dengn tim penulis memutuskan perlunya logo batik serumpun Melayu hasil penggabungan budaya Indonesia dengan Malaysia.

Adanya logo batik serumpun Melayu dapat dijadikan sebagai identitas jaminan diri suatu produk sekaligus untuk membedakan nama batik tersebut dengan milik orang lain maka diperlukan logo. Menurut Mike Mosser bahwa logo merupakan simbol merek, lembaga atau perusahaan yang disederhanakan agar khalayak mudah mengenalinya (Pujiyanto, 2016). Logo dari segi verbal dan visual yang terdiri dari unsur tulisan (huruf) dan atau gambar. Unsur tulisan yang memiliki karakter sistem masyarakat setempat yang dikenal sebagai logotype, sedangkan penampilan dalam bentuk gambar yang memiliki simbol yang memiliki makna yang diwujudkan dalam bentuk logogram (Dian, 2011). Agar logo dapat dipahami secara baik maka perlu adanya efektifitas lintas budaya dengan memiliki simbol yang dipahami masyarakat. Keberhasilan setiap logo tergantung pada masyarakat dalam mengkap simbol yang disampaikan sebagai citra suatu organisasi.

Sebuah logo, bila dicermati secara visual melalui struktur penyusunannya, dapat dikelompokkan menjadi tiga bagian, yaitu: (1) logotype atau brand name merupakan logo berbentuk verbal yang tersusun dari bentuk huruf atau rangkaian huruf yang dapat dieja, dibaca, dan diucapkan; (2) logogram atau brand mark merupakan logo berwujud visual berupa gambar yang memiliki sombol-simbol tertentu; (3) Logo combinations yaitu logo yang terbentuk atas penggabungan atau kombinasi antara brand name dan brand mark yang saling mendukung dan saling menguatkan misi logo tersebut. Untuk menghasilkan logo yang baik diperlukan kreativitas dalam merancang. Kreativitas merupakan memampuan dalam membuat kombinasi baru berdasarkan data yang diperoleh, proses berpikir dalam penggalian ide, melalui inspirasi spontan, dan pemikiran baru sehingga menghasilkan karya yang beda dari sebelumnya (Zubaedi, 2007). Dalam buku The Art of Thought yang ditulis Wallas (dalam Iswantara, 2017) proses kreatif melalui beberapa tahapan yaitu: tahap persiapan, tahap inkubasi, tahap illuminasi, dan tahap verifikasi. Lawson (2005) dalam buku berjudul How Designer Think, 
tahapan kreativitas dikembangkan menjadi: first insight, preparation, incubation, illumination, dan verification.

Kreativitas merupakan suatu proses berkarya untuk menghasilkan desain yang baru dan menarik melalui gagasannya. Desainer yang kreatif (creator) banyak memiliki ide melalui cara-cara baru yang berbeda dengan orang lain melalui cara pandang yang aneh dan unik yang dapat dipertanggungjawabkan (Pujiyanto, 2018). Kreativitas dapat dilakukan melalui proses beberapa kali demi menghasilkan ide yang dapat diimplementasikan, seperti yang dikatakan Kartajaya (2018) bahwa kreativitas merupakan penggunaan sumber daya yang ada untuk menciptakan sesuatu yang baru, antara ide dan implementasinya. Kreativitas merupakan keilmuan yang dimiliki creator dalam menemukan permasalahan urgen, pendekatan irasional menjadi rasional, pemikiran yang objektif, terobosan gagasan baru, menghasilkan karya yang baru, karya yang dapat diimplementasikan dan dapat memberi nilai tambah bagi produk, lembaga, dan masyarakat.

Kreativitas dalam perancangan logo merek primer dapat dilakukan dengan cara penggabungan budaya melalui asimilasi antar negara Indonesia dengan negara Malaysia. Asimilasi merupakan suatu proses sosial melalui usaha-usaha untuk mengurangi perbedaan-perbedaan di antara kelompok-kelompok dalam dan antar negara saling berubah serta saling menyesuaikan diri terhadap tindak, sikap dan mental dengan maksud mempererat dan mempertinggi kesatuan demi kepentingan dan tujuan bersama (Pratiwi, 2019). Menurut Vander Zanden (dalam Zakky, 2020). Asimilasi merupakan bagian dari proses interaksi sosial antar kelompok yang dilakukan mulai dari berfikir untuk saling menghargai dengan tindakan nyata berbaur sehingga memiliki identitas baru dalam kesatuan sosial. Adanya toleransi antar kebudayaan yang berbeda dalam kehidupan bermasyarakat dilakukan secara damai, karena masing-masing memiliki rasa toleransi yang saling menerima serta menyesuaikan terhadap perubahanperubahan yang ada (Berpendidikan, 2015). Asimilasi dalam lingkup budaya merupakan adanya toleransi antar kebudayaan yang saling memberi dan membutuhkan sehingga terbentuk kebudayaan baru untuk kehidupan yang damai berdampingan, sebagaimana antara Indonesia dengan Malaysia dalam menciptakan merek dan logo batik serumpun Melayu yang dapat dimiliki bersama.

\section{METODE PENELITIAN}

Penelitian dilakukan menggunakan metode deskripstif kualitatif yang sumber datanya diperoleh melalui observasi, wawancara, dokumen, dan kepustakaan. Observasi dilakukan secara langsung ke beberapa daerah seperti Medan, Riau, Padang, dan Kuala Lumpur. Wawancara dilakukan kepada narasumber yang mengetahui tentang budaya serumpun Melayu. Dokumen diperoleh melalui pengumpulan dari hasil budaya Melayu berupa elemen estetika rumah adat dan artefak yang tersimpan di Museum Adityawarman Provinsi Sumatera Barat, Museum Sang Nila Utama Provinsi Riau, Istana Maimun Medan, Muzium Diraja Malaysia, dan Muzium Negara Malaysia. Kepustakaan diperolah melalui literatur naskah lama dan referensi yang berhubungan dengan budaya Melayu, batik Melayu, dan teori-teori yang berhubungan dengan konten penelitian ini. 
Sebelum analisis dilakukan verifikasi kevalidan data melalui teknik triangulasi antar jenis data, bentuk data, sumber data, dan antar peneliti, selanjutnya dilakukan analisis data. Agar lebih mengena pada hasil perancangan desain, maka analisis menggunakan teori kreativitas desain miliknya Lawson (2005), dalam mendesain terdapat lima tahapan proses yaitu: first insight, preparation, incubation, illumination, dan verification, seperti gambar 1.

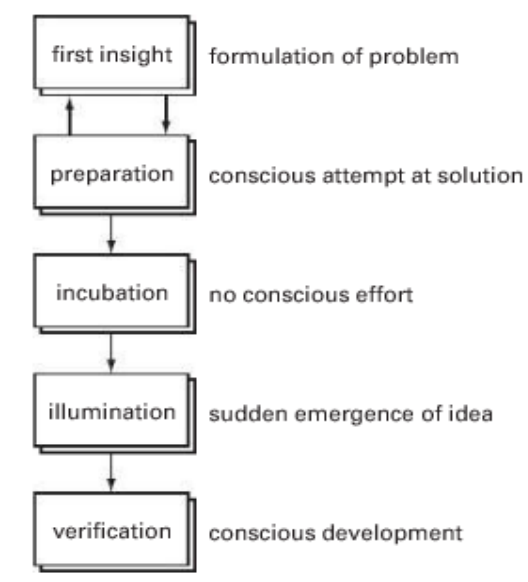

Gambar 1. Proses evolusi desain logo [Sumber: Lawson, 2005]

\section{HASIL DAN PEMBAHASAN}

Hasil dan pembahasan dalam penelitian dan perancangan ini dilakukan melalui beberapa tahapan, yaitu mulai mengetahui masalah, penggalian data, penggalian ide, visualisasi desain, hingga menghasilkan desain dan implementasinya. Secara runtun penulis (perancang) melakukan beberapa tahapan proses mendesain yaitu: first insight, preparation, incubation, illumination, dan verification.

\section{a. First Insight}

Pengertian awal, penulis (perancang) memerlukan pemahaman adanya masalah yang terjadi di lapangan dari peneltian sebelumnya berjudul Penggalian, Pengembangan, dan Akulturasi Budaya Melayu Sebagai Jatidiri Bangsa Serumpun Untuk Menghindari Ego Culture Asia (Pujiyanto et al, 2019). Pada selanjutnya secara eksis dan komitmen memahaminya secara utuh mencari rumusan masalah serta tujuan perancangan. Pada tahapan awal sudah terciptanya batik yang memiliki spirit kebudayaan Melayu untuk pemerkuat antar daerah dan bangsa serumpun Melayu Indonesia dengan Malaysia. Batik serumpun Melayu dalam perkembangannya hingga kini belum memiliki identitas diri selayaknya "anak yang belum memiliki nama" yaitu logo. Identitas ini sangat diperlukan sebagai media untuk memperkuat hubungan diplomatik melalui produk yang memiliki logo nama merek primer sebagai jati diri batik serumpun Melayu IndonesiaMalaysia.

\section{b. Preparation}

Menurut Wallas (dalam Iswantara, 2017) tahap persiapan merupakan proses pengumpulan data dan informasi, mempelajari pemikiran orang lain, wawancara kepada ahli untuk mencari jawabannya. Dalam proses desain dilakukan prose persiapan, 
secara sadar menggali data sebagai pondasi mengembangkan gagasan dalam pemecahan masalah. Dalam kegiatan ini, penulis bekerja keras observasi ke lokasi yang memiliki artefak budaya Melayu. sebagai sampelnya adalah kota Medan, Riau, Padang, dan Kuala Lumpur. Data lain adalah budaya yang berkaitan dengan adat istiadat, kepercayaannya dan pola hubungan kemasyarakatannya, serta hasil budayanya yang terdapat pada arsitektur, elemen setetik interior, seni dan kerajinan yang sangat melekat dengan KeMelayuannya. Seluruh data yang diperoleh lalu disimpan, sebagai dasar proses selanjutnya untuk didistribusikan, diproduksi, dikonsumsi, dipadatkan, disuplikasikan hingga menghadirkan data lain yang siap untuk dipergunakan mendesain, menurut Kartajaya (2017) ini merupakan cara mengombinasikan data atau knowledge. Melalui data yang diperoleh inilah sebagai dasar dalam menggali ide kreatif dalam bentuk visual dan pesan verbal.

\section{1) Ide Kreatif Visual}

Ide ini diperoleh melalui wujud visual dari beberapa artefak Melayu yang dianggap dapat mewakili Indonesia dengan Malaysia. Bentuk visual melalui penggalian hasil budaya Melayu dieksplor menjadi karya desain. Penggalian dilakukan observasi (pengamatan) terhadap artefak Melayu yang dipadukan dengan referensi-referensi yang ada hubungannya nama, pengertian, fungsi, dan simbol-simbol yang melekat pada artefak yang dibutuhkan, sebagai contoh artefak atap langit, pucuk rebung, ragam hias sulur, dan motif wajik.

\section{a) Selembayung (Atap Langit)}

Selembayung merupakan dua benda bersilang sebagai hiasan ujung bangunan rumah melayu, seperti rumah dan perkantoran di kota Riau dan di Kuala Lumpur (gambar 2). Hiasan tersebut terdiri dari dua pasang yaitu bagian kanan sebagai Selembayung jantan dan bagian kiri sebagai Selembayung betina. Antara Selembayung kanan dan kiri disatukan menyimbolkan adanya kekerabatan, kesatuan, keharmonisan, keserasian dalam berumah tangga.

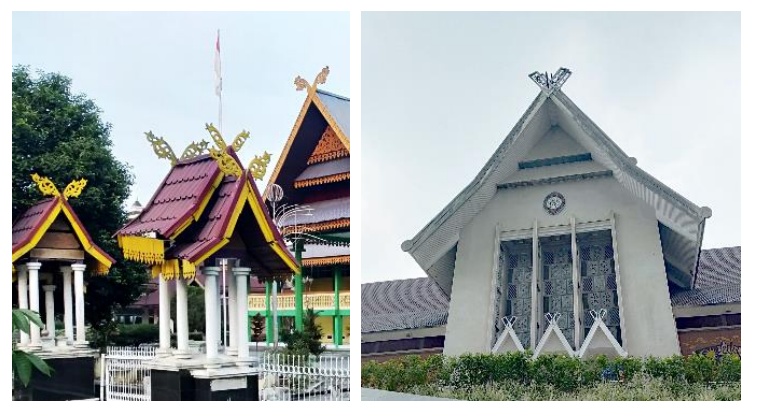

Gambar 2. Atap langit pada Museum Sang Nila Utama Provinsi Riau dan Muzium Negara Malaysia

(Sumber: Dokumentasi Penulis)

Di sisi lain Selembayung sebagai mahkota suatu bangunan yang memberi kepercayaan adanya cahaya bangunan sebagai keseraian hidup, kewibawaan, mendatangkan keuntungan dan keselamatan bagi tuan rumah. Selembayung kadang diberi hiasan daun-daunan dan bunga yang melambangkan adanya kasih sayang, 
tahu adat, berkelanjutan keturunan dan harmonis dalam rumah tangga (Al Mudra, 2004 dan Riau Magazine, 2017). Bagi Dora (2018), sistem kekerabatan dalam budaya Melayu seperti bertempat di ujung gading yang kekerabatan selalu dijunjung tinggi keturuannya mulai keturunan dari ke atas ke bawah hingga tak terbatas.

b) Pucuk Rebung

Pucuk Rebung (Pucuak Rabuang) merupakan tunas bambu yang masih muda yang deformasikan menjadi bentuk segi tiga (gambar 3). Motif Pucuk Rebung berbentuk segi tiga meruncing ke atas yang terdapat ranting di sisi kanan dan kiri sebagai deformasi pucuk bambu yang tumbuh terubus menyimbolkan kesuburan dan kebahagiaan dalam kehidupan manusia (Al Mudra, 2004).

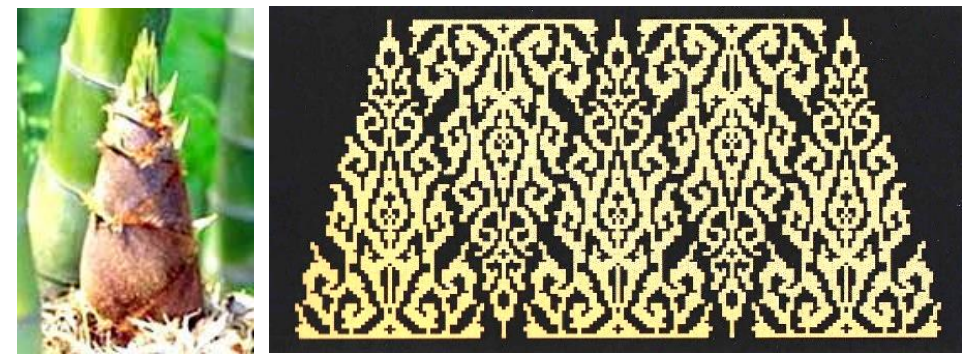

Gambar 3. Pucuk Rebung sebagai ide perancangan motif Pucuk Rebung (Sumber: https://www.freepik.com/ dan https://riauberbagi.blogspot.com/)

Di daerah Riau, motif jenis ini sering digunakan untuk hiasan pinggir kain tenun dan sulam. Dalam katalog "Pemeran Khusus Ragam Hias Pakaian Pengenting Tradisional Se-Sumatera" yang ditulis oleh Purba (1997) Pucuk Rebung di daerah Aceh menyimbolkan adanya bimbingan dari orang tua ke generasi muda. Di Sumatera Barat menyimbolkan manusia berguna bagi dirinya maupun orang lain, sedangkan daerah Lampung menyimbolkan kehidupan baru dan berkembang dalam kehidupan berkeluarga. Motif ini juga menyimbolkan adanya hubungan spiritual antara manusia kepada Sang Pencipta serta masyarakat kepada pemimpinnya (Ardiansyah, 2019). Menurut Muasri (2012) motif Pucuk Rebung sebagai bahasa tanda adanya anjuran kepada manusia agar hidupnya dapat berguna untuk semua orang. Di samping itu, bentuk Pucuk Rebung yang masih muda mencuat lurus ke atas, menyimbolkan tentang petuah bagi generasi muda supaya selalu menuntut ilmu pengetahuan agar dapat teraih cita-citanya.

c) Ragam Hias Sulur

Sulur merupakan jenis tumbuh-tumbuhan darat yang menjalar. Tumbuhan Sulursuluran terdiri dari bagian batang, ranting, tangkai, daun, dan bunga yang mengalami perubahan bentuk dan fungsi yang diaplikasikan sebagai hiasan pelengkap estetik interior rumah adat. Hiasan sulur di kota Padang dapat ditemui pada rumah adat dan museum Museum Nagari Adityawarman Provinsi Sumatera Barat (gambar 4). Tumbuhan jenis Sulur merupakan tumbuhan menjalar yang bersambung berkaitan sebagai simbol adanya kedinamisan manusia yang gigih dan ulet untuk memenuhi kehidupannya. 


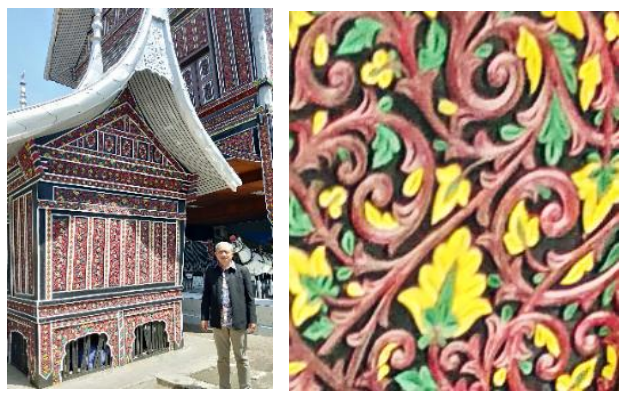

Gambar 4. Ragam Hias Sulus pada

Museum Nagari Adityawarman Provinsi Sumatera Barat

(Sumber: Dokumentasi Penulis)

Menurut Purba (1997) motif Sulur di daerah Sumatera Barat dalam penerapannya disesuaikan berdasarkan adat, di Sumatera Selatan sebagai lambang kehidupan, dan di Bengkulu memiliki simbol kesejukan dan keserhanaan, sedangkan di Bengkulu menyimbolkan suatu kehidupan manusia yang penuh liku-liku. Menurut Muasri (2012) tumbuhan yang merambat menyimbolkan adanya orang perantauan perlu kekuatan, kegigihan, dan keuletan guna mencapai tujuan hidup.

d) Motif Wajik (Belah Ketupat)

Wajik merupakan bentuk persegi empat menyerupai belah ketupat. Motof ini banyak dipergunakan pada produk kerajinan songket Melayu yang biasa digunakan sebagai pakaian adat pada kegiatan upacara pernikahan (gambar 5).
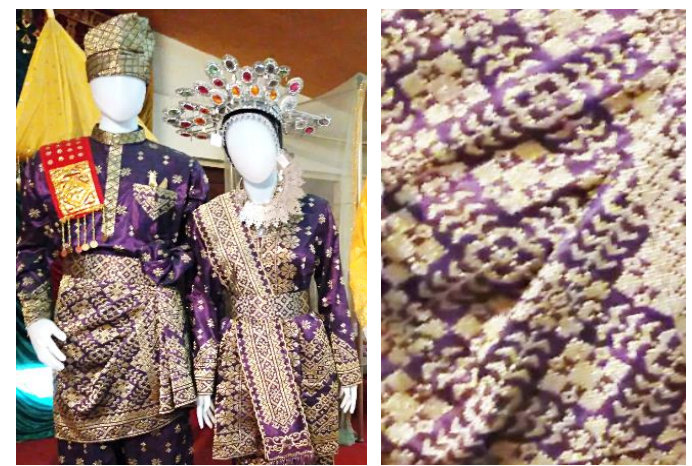

Gambar 5. Motif wajik yang terdapat pada kain songket (Sumber: Dokumentasi Penulis)

Motif wajik terdapat empat titik sudut atas, kanan, bawah, dan kiri yang menunjukkan empat arah. Bila ditemukan titik bawah dengan titik atas membentuk garis vertikal, begitu juga titik kiri ditemuka dengan titik kanan menghasilkan garis horizontal. Dua garis ini memiliki simbol kehidupan manusia di dunia, antara hubungan secara horizontal sesama manusia, sedangkan garis vertikal menyimbolkan adanya hubungan manusia dengan Tuhannya. Di daerah Melayu menyimbolkan masrayakatnya memiliki jiwa sosial yang tinggi, membaur, keterbukaan, memerima serta memperlakukan siapapun yang berniat baik. Tolongmenolong dan toleransi dalam kehidupan masyarakat tanpa memandang status dan golongan (Ardiansyah, 2019). 


\section{2) Ide Kreatif Verbal}

Ide kreatif verbal dilakukan melalui pengelompokan jenis dan karakter huruf untuk dipilah dan dipilih sebagai dasar dalam memperkuat ide kreatif viasul. Agar lebih dekat pada ciri khas suatu negara diperlukan pemahaman tentang sifat dan psikologi huruf untuk diterapkan pada logo batik yang mengandung unsur: batik, asimilasi, Indonesia, dan Malaysia yang disatukan menjadi batik "Asimilasi Indolaysia". Berdasarkan unsur ini dilakukan pemilihan huruf "i" sebagai nama negara Indonesia dan huruf "M" sebagai nama negara Malaysia, seperti pada tabel 1.

Tabel 1. Ide kreatif verbal

(Sumber: Dokumentasi Penulis)

\begin{tabular}{|c|c|}
\hline Huruf Verbal & Pengertian \\
\hline & $\begin{array}{l}\text { Pemilihan huruf Futura Bk BT yang sesuai untuk mewakili } \\
\text { inisial "A" yang diambil dari kata "Asimilasi": memiliki } \\
\text { pengertian menyatunya antar budaya daerah atau negara } \\
\text { yang sama kuatnya untuk saling, mengisi, menghargai } \\
\text { demi kepentingan dan tujuan bersama. }\end{array}$ \\
\hline $\mathrm{i}$ & $\begin{array}{l}\text { Jenis huruf Brush Script MT dipilih sebagai menyerupai } \\
\text { jenis tanaman yang menjalar, sebagai tanda di Indonesia } \\
\text { sebagai negara agraris. Huruf "I" merupakan huruf depan } \\
\text { dari nama "Indonesia", sebagai perwakilan adanya budaya } \\
\text { Melayu yang ada di negara ini. }\end{array}$ \\
\hline $\mathrm{M}$ & $\begin{array}{l}\text { Jenis huruf yang terpilih adalah Century Gothic, sebagai } \\
\text { bangunan modern yang sering diandalkan di negara } \\
\text { Malaysia, seperti gedung kembar Petronas. Penggunaan } \\
\text { huruf "M" merupakan singkatan (inisial) dari nama } \\
\text { "Malaysia", yang mewakili budaya Melayu yang ada di } \\
\text { negara ini. }\end{array}$ \\
\hline
\end{tabular}

\section{c. Incubation}

Inkubasi merupakan proses "pengeraman alam prasadar" hingga munculah sebuah gagasan secara mendadak (iluminasi). Melalui kerja otak tanpa sadar selama periode inkubasi dalam penataan dan kajian berulang-ulang berdasarkan ide logo agar menjadi beda dan baru. Proses ini dilakukan terus menerus melalui asimilasi, yaitu percampuran dua karakter desain artefak yang sama kuatnya sehingga menghasilkan desain baru dengan cara menggunakan pendekatan deformasi sebagai proses penyederhanaan bentuk suatu objek, yaitu dari bentuk dasar yang melekat pada benda dirubah menjadi bentuk lain. Perubahan bentuk dari yang kompleks kerumitannya menjadi sebuah bentuk karakter yang sederhana tanpa menghilangkan bentuk, makna, maksud dan arti dari bentuk aslinya.

Bentuk baru sebagai hasil deformasi kemudian diolah melalui pendekatan metafora untuk melebih-lebihkan dan menguatkan pesan. Ciri-ciri dari deformasi bentuk dalm desain komunikasi visual, antara lain: (1) bentuknya sederhana, (b) mempunyai arti yang 
kuat, (3) dapat menginformasikan secara cepat, (4) memberi makna lugas sesuai pesan yang diinformasikan, dan (5) mudah dimengerti arti dan maksudnya melalui visual gambar. Proses inkubasi dalam perancangan ini dilakukan melalui perenungan dan asimilasi artefak budaya Indonesia dengan Malaysia hingga menghasilkan bentuk baru yang mengarah pada batik "Asimilasi Indolaysia", seperti pada tabel 2.

Tabel 2. Proses Deformasi Artefak Melayu

(Sumber: Dokumentasi Penulis)

\begin{tabular}{|c|c|c|c|c|c|}
\hline \multirow{2}{*}{ No } & \multicolumn{2}{|c|}{ Artefak Melayu } & \multicolumn{2}{|c|}{ Deformasi } & \multirow{2}{*}{ Keterangan } \\
\hline & Indonesia & Malaysia & Pertama & Kedua & \\
\hline 1 & & & & & $\begin{array}{l}\text { Selembayung (Atap } \\
\text { Langit) tampak pada } \\
\text { rumah adat Melayu } \\
\text { khususnya di Riau dan } \\
\text { Kuala Lumpur. }\end{array}$ \\
\hline 2 & & & & & $\begin{array}{l}\text { Pucuk Rebung banyak } \\
\text { terlihat di berbagai } \\
\text { produk kriya tekstil, } \\
\text { kriya logam, dan kriya } \\
\text { kayu. }\end{array}$ \\
\hline 3 & (5) & & & & $\begin{array}{l}\text { Ragam hias Sulur yang } \\
\text { sering ditemui pada } \\
\text { ukiran kayu yang } \\
\text { dipasang di dinding } \\
\text { dan atas pintu masuk } \\
\text { rumah adat. }\end{array}$ \\
\hline 4 & $\begin{array}{l}\text { HA AU } \\
\text { Hown }\end{array}$ & $88 \%$ & & & $\begin{array}{l}\text { Motif Wajik (Belah } \\
\text { Ketupat) banyak } \\
\text { terdapat pada benda } \\
\text { kriya tekstil, seperti } \\
\text { pada kain songket. }\end{array}$ \\
\hline 5 & $\mathrm{i}$ & $\mathrm{i}$ & & & $\begin{array}{l}\text { Huruf "i" merupakan } \\
\text { jenis huruf Brush Script } \\
\text { MT, memiliki sifat } \\
\text { lentur yang } \\
\text { menyesuaikan karakter } \\
\text { alam. }\end{array}$ \\
\hline 6 & M & M & & & $\begin{array}{l}\text { Huruf “M” merupakan } \\
\text { jenis huruf Century } \\
\text { Gothic, memiliki sifat } \\
\text { tegas yang } \\
\text { menyesuaikan karakter } \\
\text { bangunan. }\end{array}$ \\
\hline 7 & 0 & 0 & & & $\begin{array}{l}\text { Titik merupakan } \\
\text { tetesan lilin dalam } \\
\text { membatik, fungsinya } \\
\text { sebagai isen motif } \\
\text { batik. }\end{array}$ \\
\hline
\end{tabular}




\section{d. Illumination}

Menurut Besemer dan Treffinger (dalam Aziz, 2018 dan Iswantara 2017) hasil karya desain yang kreatif terdapat pada: (1) kebaruan (novelty) yaitu desain yang memiliki unsur-unsur baru dari segi ide, teknik, dan konsep yang tercermin pada keunikan dan penakjuban desain, (3) pemecahan (resolution) yaitu adanya pemenuhan kebutuhan dalam mengatasi masalah yang memiliki kriteria masuk akal, bermanfaat, bernilai, bermakna, dan berguna bagi dirinya dan masyarakat, dan (3) bentuk (style) yaitu desain yang dihasilkan memiliki bentuk yang beda dengan desain sebelumnya, di dalamya terdapat kesempurnaan dan dapat dipahami dari segi visual, verbal, dan bobot isi. Untuk mencapai desain yang maksimal diperlukan penggalian ide melalui berbagai pendekatan kefahaman Islami secara terus menerus untuk mendapatkan gagasan secara tiba-tiba.

Berdasarkan kepercayaan Islam, maka dalam logo didekatkan pada masyarakat Melayu yang menghindari gambar makhluk bernyawa, maka dalam mendesain dibatasi pada unsur flora dan unsur geometris. Hal mengacu pada hadist HR. Bukhari, meriwayatkan Rasulullah SAW bersabda, "barang siapa menggambar suatu makhluk yang bernyawa di dunia, maka dia akan diminta untuk meniupkan ruh kepada gambarnya itu kelak di hari akhir, sedangkan dia tidak kuasa untuk meniupkannya". Permasalahan inilah yang menjadi perhatian khusus dalam penggalian ide dalam pembuatan logo yang dilakukan penggalian secara terus menerus hingga mencapai titik klimak hingga menghasilkan beberapa alternatif desain. Beberapa alternatif inilah dipilih yang terbaik untuk dikembangkan melalui proses evolusi desain dengan mempertimbangkan ke arah logogram dan logotype. Di samping itu, alternatil desain juga diarahkan pada bentuk, warna, pesan visual, pesan verbal, menarik, sederhana, komunikatif, berbobot, indah secara tektual dan kontektual sehingga terpilihlah karya desain logo batik "Asimilasi Indolaysia" yang terbaik.

\section{1) Alternatif Logogram}

Perancangan logogram bersumber ide dari Pucuk Rebung yang diolah melalui proses evolusi dan deformasi sehingga menghasilkan beberapa alternatif desain logo (gambar 6). Dari beberapa desain logo didiskusikan tim penulis untuk dipilih satu berdasarkan kesederhanaan, menarik, komunikatif, serta konsep kelslaman dalam batik "Asimilasi Indolaysia".

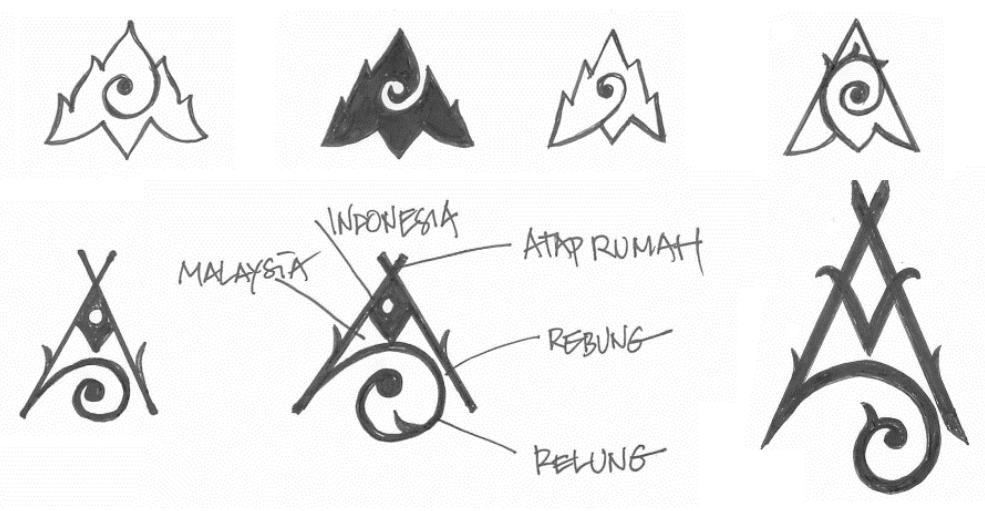

Gambar 6. Proses evolusi dalam menghasilkan logogram (Sumber: Dokumentasi Penulis) 


\section{2) Alternatif Logotype}

Perancangan logotype dilakukan pemilihan huruf yang lembut disesuaikan dengan karakter nama batik milik dua negara, yaitu Indonesia dan Malaysia. Pemilihan beberapa huruf berdasarkan bentuk dan karakter yang diaplikasikan ke dalam bahasa verbal berupa kalimat batik "Asimilasi Indolaysia" sebagai nama merek primer (tabel 3). Dari beberapa alternatif dipilih satu yang terbaik untuk disandingkan dengan logogram.

Tabel 3. Alternatif logotype

(Sumber: Dokumentasi Penulis)

\begin{tabular}{|l|l|}
\hline $\begin{array}{l}\text { BATIK ASIMILASI INDOLAYSIA } \\
\text { Pemersatu Budaya Melayu (Huruf Rockwell) }\end{array}$ & $\begin{array}{l}\text { BATIK ASIMILASI INDOLAYSIA } \\
\text { Pemersatu Budaya Melayu (Huruf Bell MT) }\end{array}$ \\
\hline $\begin{array}{l}\text { BATIK ASIMILASI INDOLAYSIA } \\
\text { Pemersatu Budaya Melayu (Huruf Bodoni Bk BT) }\end{array}$ & $\begin{array}{l}\text { BATIK ASIMILASI INDOLAYSIA } \\
\text { Pemersatu Budaya Melayu (Huruf Times New Roman) }\end{array}$ \\
\hline $\begin{array}{l}\text { BATIK ASIMILASI INDOLAYSIA } \\
\text { Pemersatu Budaya Melayu (Huruf Sitka Heading) }\end{array}$ & $\begin{array}{l}\text { BATIK ASIMILASI INDOLAYSIA } \\
\text { Pemersatu Budaya Melayu (Huruf EB Garamond) }\end{array}$ \\
\hline
\end{tabular}

\section{e. Verification}

Wallas (dalam Iswantara, 2017) menegaskan pada tahapan ini dilakukan melelui proses divergensi dan konvergensi hingga verifikasi secara sadar dari hasil logo batik "Asimilasi Indolaysia" untuk diuji kelayakan melalui implementasi ke berbagai tempat dan media. Menurut Kartajaya (2017) Ide yang telah diwujudkan ke dalam desain logo perlu diimpletasikan, bila tidak diimplementasikan, hal ini belum mengarah pada kretaivitas yang sebenarnya. Maka pada desain kahit dilakukan tahap pengujian melalui pemikiran kreatif (divergensi) yang dipadu pemikiran kritis (konvergensi) untuk diaplikasikan atau diimplementasikan secara relatitas yang benar-benar sehingga logo dapat diterapkan sesuai fungsinya.

\section{1) Konsep Logo}

Logo batik "Asimilasi Indolaysia" merupakan simbol merek primer yang melekat pada logogram dan logotype. Logogram mengambil berbagai unsur artefak yang memiliki simbol-simbol budaya Melayu, antara lain: (a) Selembayung memiliiki simbol keharmonisan dan keserasian dalam berumah tangga; (b) Pucuk Rebung menyimbolkan manusia hidup berguna untuk semua makhuk; (c) Ragam hias Sulur menyimbolkan bahwa manusia selalu berhubungan dengan orang lain; (d) Motif Wajik mentimbolkan empat arah (Timur, Selatan, Barat, Utara) merupakan jalan hidup manusia; (e) Titik artinya manunggal yang menyimbolkan menyatunya manusia dengan Tuhannya; ( $f$ ) Warna emas merupakan simbol harapan manusia agar diberi kemuliaan dan kejayaan; dan (g) Hitam menyimbolkan kelanggengan, bahwa manusia di dunia agar selalu beribadah kepada Tuhannya untuk bekal kelanggengan diakherat. Perwakilan tiga huruf alphabet dalam logotype berupa huruf " $A$ " merupakan singkatan dari kata "asimilasi", huruf "i" singkatan dari negara Indonesia, dan " $M$ " merupakan singkatan dari negara Malaysia, seperti pada gambar 7. 


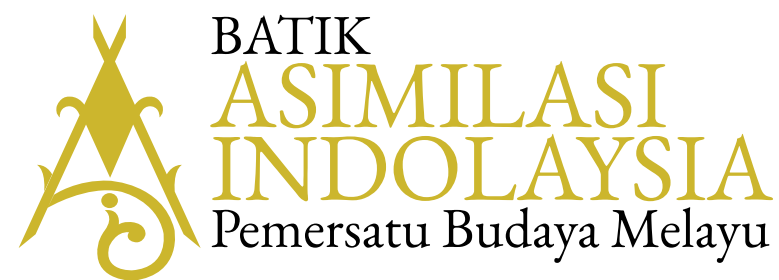

Gambar 7. Logo yang telah jadi

(Sumber: Dokumentasi Penulis)

Dari segi kenegaraan, batik "Asimilasi Indolaysia" merupakan hasil kolaborasi budaya serumpun Melayu antara Indonedia dengan Malaysia, diharapkan kedua negara terjalin hubungan diplomatik yang lebih baik. Dari segi produk dan merek batik ini memeiliki positioning masyarakat melayu dan masyarakat Islami. Harapannya bagi yang memakai baik ini diberi keharmonisan, keserasian, kelanggengan dalam kemulyaan, kejayaan, kehidupan yang mapan, maka pilihanya hanya satu batik "Asimilasi Indolaysia".

2) Implementasi Logo

Uji coba dam iplementasi dilakukan di beberapa tempat atau media, sebagai contoh di tempat perusahaan, toko batik, tas belanja batik, dan media lainnya. Melalui implementasi desain logo batik "Asimilasi Indolaysia" terlihat adanya keserasian, komunikatif, dan menarik calon konsumen, seperti gambar 8 .
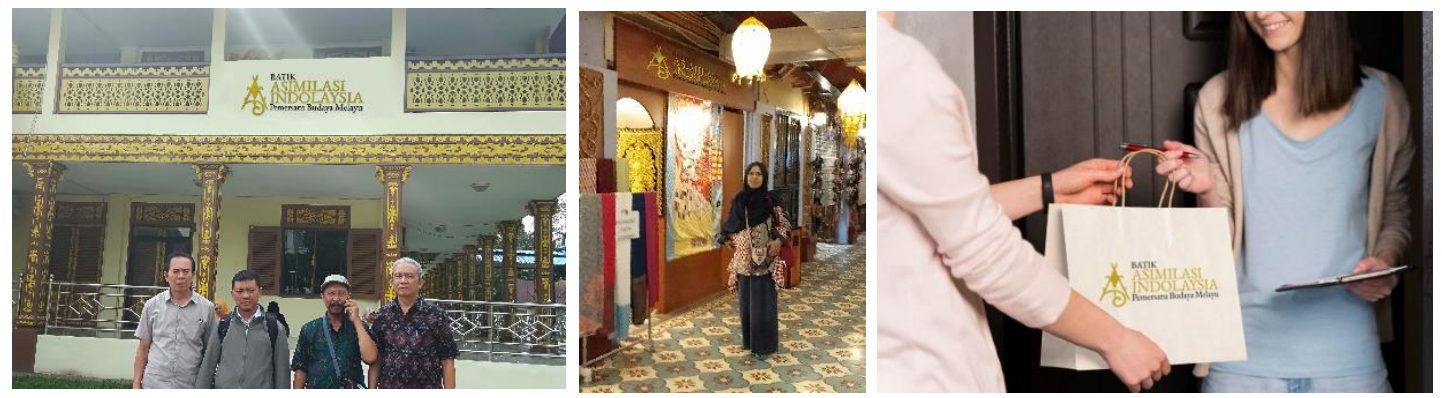

Gambar 8. Impelmentasi logo di beberapa tempat dan media

(Sumber: Dokumentasi Penulis, dan https://www.freepik.com/)

\section{KESIMPULAN}

Perancangan logo merek pada batik serumpun Melayu dilakukan melalui pra desain, desain, dan paska desain. Pra desain dilakukan melalui tahapan first insight, serta preparation merupakan proses pencarian hingga memahami permasalahan tentang batik serumpun Melayu Indonesia-Malaysia. Beberapa artefak-artefak budaya Melayu ada melekat di Negara Indonesia dengan Malaysia, seperti artefak Selembayung, Pucuk Rebung, Ragam Hias Sulur, dan Motif Wajik sebagai dasar ide untuk divisualkan pada logogram. Sebagai unsur verbal dalam logo dilakukan pemilahan dan pemilihan huruf yang sesuai untuk logotype. Berdasarkan artefak dan huruf yang terpilih dilakukan incubation dan illumination hingga menghasilkan bentuk deformasi yang diperkuat dengan metafora bentuk dan simbol. Dari bentuk atap rumah Selembayung yang dipadukan dengan Pucuk Rebung menjadi huruf " $A$ " dari kata "asimilasi", huruf " $i$ " singkatan dari nama negara Indonesia, serta huruf " $M$ " merupakan singkatan dari nama negara Malaysia. Bila ketiganya digabungkan memberi pengertian adanya kesatuan 
budaya serumpun Melayu antara Indonesia dengan Malaysia. Pada paska desain dilakukan verification sehingga menghasilkan logo batik "Asimilasi Indolaysia" yang diaplikasikan di beberapa tempat dan media promosi. Terciptanya logo ini sebagai penguat produk batik serumpun Melayu yang dapat dimiliki bersama, dan dapat dikembangkan bersama melalui titian muhibah antara Indonesia dengan Malaysia.

\section{DAFTAR PUSTAKA}

Al Mudra, Mahyudi. (2004) Rumah Melayu: Memangku Adat Menjemput Zaman, Yogyakarta: Balai Kajian dan Pengembangan Budaya Melayu, 38-44, 91

Ardiansyah. (2019). Kebung, Motif Belah Ketupat dan Makna filosofi di Dalamnya, https://www.andrianstory.com/2019/09/kebung-motif-belah-ketupat-danmakna.html, diakses 12 Juni 2020

Aziz, Rahmat. (2018). Creative Learning, Malang: Edulitera, 28

Berpendidikan. (2015). Pengertian Asimilasi dan Akulturasi Kebudayaan beserta Contohnya. Lengkaphttps://www.berpendidikan.com/2015/09/pengertianasimilasi-dan-akulturasi-kebudayaan-beserta-contohnya-lengkap.html, diakses 2 Juni 2020.

Dian, Mas dan Jessica Diana Kartika. (2011). Feng Shui Untuk Logo, Jakarta: Elex Media Komputindo, 9-12.

Dora, Nur Iza. (2018) Kajian Kearifan Lokal Masyarakat "Melayu" Ujung Gading, Jurnal Ijtimaiyah Vol.2 No.1 Januari-Juni 2018, ISSN 2541-660X, 3

Iswantara, Nur. (2017). Kreativitas: Sejarah, Teori \& Perkembangan. Yogyakarta: Gigih Pustaka Mandiri, 48-50.

Kartajaya, Hermawan. (2017). Citizen 4.0: Menjejakkan Prinsip-prinsip Pemasaran Humanis di Era Digital, Jakarta: Kompas Gramedia, 166, 213.

Kartajaya, Hermawan. (2018). Planet OMNI: The New Yin Yang of Business, Jakarta: Gramedia Pustaka Utama, 109.

Lawson, Bryan. (2005). How Designer Think (Fourth Edition), Oxford: Architectural Press, 149.

Muasri (Editor). (2012) Ragam Hias Pada Koleksi Museum Adityawarman, Padang: Dinas Kebudayaan dan Pariwisata Provinsi Sumatera Barat, 19-22.

Pratiwi, Poerwanti Hadi. (2019). Asimilasi Dan Akulturasi: Sebuah Tinjauan Konsep. http://staffnew.uny.ac.id/upload/132326892/pengabdian/asimilasiakulturasi.pdf

Pujiyanto, Robby Hidajat, Andy Pramono, dan Ahmad Tarmizi Bin Azizah. (2019). Penggalian, Pengembangan, dan Akulturasi Budaya Melayu Sebagai Jatidiri Bangsa Serumpun Untuk Menghindari Ego Culture Asia (Penelitian PNBP UM), Malang: Universitas Negeri Malang, 122

Pujiyanto. (2016). Desain Kemasan Produk Persuasif, Malang: Penerbit \& Percetakan Universitas Negeri Malang, 195.

Pujiyanto. (2018). Jiwa Entrepreneurship Penggerak Desain, Jurnal Andharupa, Volume 04 Nomor 02, Agustus 2018, 241.

Purba, Suruhen. (1997). Katalog Pemeran Khusus Ragam Hias Pakaian Pengenting Tradisional Se-Sumatera, Medan: Museum Negeri Provinsi Sumatera Utara, 6, 17. 
Riau Magazine. (2017). Selembayung Riau - Warisan Budaya Tak Benda Riau. https://www.riaumagz.com/2017/10/selembayung-riau-warisan-budayatak.html, diakses 15 Juni 2020.

Zakky. (2020). Pengertian Asimilasi: Definisi, Ciri-Ciri, Syarat, Faktor, dan Contohnya. https://www.zonareferensi.com/pengertian-asimilasi, diakses 2 Juni 2020.

Zubaedi. (2017). Strategi Taktis Pendidikan Karakter, Depok: RajaGrafindo Persada, 107.

Sumber Gambar

https://www.freepik.com/free-photo/front-view-woman-handing-delivery-whileholding-notepad-pen_8531062.htm

https://riauberbagi.blogspot.com/2016/10/corak-tenun-melayu-riau.html

https://www.freepik.com/free-photo/front-view-woman-handing-delivery-whileholding-notepad-pen_8531062.htm 